Jurnal Mahasiswa BK An-Nur : Berbeda, Bermakna, Mulia

Volume 7 Nomor 3 Tahun 2021

Tersedia Online: https://ojs.uniska-bjm.ac.id/index.php/AN-NUR

p-ISSN. 2460-9722 | e-ISSN. 2622-8297

\title{
HUBUNGAN KONSEP DIRI DAN AKTUALISASI DIRI DENGAN RESILIENSI MAHASISWA UNIVERSITAS SELAMAT SRI KENDAL YANG BEKERJA
}

\author{
Mujidah $^{1}$, Laelatul Anisah ${ }^{2}$, Mochamad Widjanarko ${ }^{3}$ \\ ${ }^{1,2}$ Universitas Selamat Sri \\ ${ }^{3}$ Universitas Muria Kudus \\ E-mail: laelatulanisah89@gmail.com /No. HP 08112512511
}

\begin{abstract}
ABSTRAK
Penelitian ini bertujuan untuk mengetahui hubungan antara konsep diri dan aktualisasi diri dengan resiliensi mahasiswa Universitas Selamat Sri Kendal yang bekerja. Hipotesis yang diajukan dalam penelitian ini ada tiga yakni : hipotesis mayor menunjukkan adanya hubungan antara konsep diri dan aktualisasi diri dengan resiliensi mahasiswa Universitas Selamat Sri Kendal yang bekerja.

Hipotesis minor pertama menunjukkan adanya hubungan antara konsep diri dengan resiliensi mahasiswa Universitas Selamat Sri Kendal yang bekerja. Hipotesis minor kedua menunjukkan adanya hubungan antara aktualisasi diri dengan resiliensi mahasiswa Universitas Selamat Sri Kendal yang bekerja. Subjek dalama penelitian ini adalah 50 mahasiswa Universitas Selamat Sri Kendal yang bekerja. Penelitian ini menggunakan teknik aksidental sampling. Pengumpulan data menggunakan skala resiliensi, konsep diri dan aktualisasi diri. Hasil pengujian hipotesis mayor dengan menggunakan analisis regresi sederhana menunjukkan hasil $R x 1, x 2, y=$ 0,751 dengan $F=30,480$ dan $p=0,000(p<0,01)$.

Hal tersebut menunjukkan adanya hubungan yang sangat signifikan antara konsep diri, aktualisasi diri dengan resiliensi mahasiswa yang bekerja. Sedangkan hasil pengujian hipotesis minor menggunakan metode analisis data dengan teknik korelasi product moment. Berdasarkan analisis pada hipotesis minor satu menunjukkan adanya hubungan positif yang signifikan antara konsep diri dengan resiliensi mahasiswa yang bekerja, ditunjukkan dengan nilai $r x l, y=0,617$ dan $p=0,000(p<0,01)$. Pada uji hipotesis minor dua menunjukkan adanya hubungan positif antara aktualisasi diri dengan resiliensi mahasiswa yang bekerja, ditunjukkan dengan nilai $r x 2, y=0,327$ dan $p=0,006(p<0,01)$.
\end{abstract}

Kata Kunci: konsep diri, aktualisasi diri, resiliensi

\section{ABSTRACT}

This research aim to know the relationship between self-concept and self-actualization with the resilience student University Selamat Sri Kendal worked. The hypothesis suggest in the study are three : the major hypothesis suggest a connection between self-concept and self-actualization with the resilience University Selamat Sri Kendal worked.

The first minor hypothesis suggest a connection between self-concept and resilience student University Selamat Sri Kendal worked. The second minor hypothesis suggest a connection between self-actualization and resilience student University Selamat Sri Kendal worked. The subject of this study was 50 student University Selamat Sri Kendal worked. This study is using a accidental sampling technique. Data gathering use scale resilience, self-concept and self-actualization. The testing of the major hypotheses by using simple regression analysis shows result $R x 1, x 2, y=0,751$ with $F=30,480$ and $p=0,000$ ( $p<0,01)$.

It suggest a correlation between self-concept and self-actualization with resilience student University Selamat Sri Kendal worked. Whereas the results of a minor hypotheses test are product moment. Based on the data analysis of the minor hypothesis one indicates a significant positive link between the self-concept and the working student resilience, showed a value of $r x 1, y=0,617$ and $p=0,000(p<0,01)$. At the minor hypothesis test two was a positive connection between self-actualization with the working student resilience, showed a value of $r x 2, y=0,327$ and $p=0,006(p<0,01)$.

Keywords: self-concept, self-actualization, resilience

Dipublikasikan Oleh :

UPT Publikasi dan Pengelolaan Jurnal

Universitas Islam Kalimantan Muhammad Arsyad Al-Banjari Banjarmasin 


\section{Mujidah $^{1}$, Laelatul Anisah ${ }^{2}$, Mochamad Widjanarko ${ }^{3}$ \\ Jurnal Mahasiswa BK An-Nur : Berbeda, Bermakna, Mulia \\ Volume 7 Nomor 2 Tahun 2021 \\ Tersedia Online: https://ojs.uniska-bjm.ac.id/index.php/AN-NUR}

p-ISSN. 2460-9722 | e-ISSN. 2622-8297

\section{PENDAHULUAN}

Pendidikan di perguruan tinggi pada saat ini bukanlah suatu hal yang mustahil untuk dicapai setiap orang. Syarat mengenyam pendidikan tersebut tidak harus memiliki inteligensi yang tinggi, mendapat beasiswa pendidikan atau berasal dari keluarga yang mampu secara finansial. Tetapi saat ini pendidikan di perguruan tinggi bisa di jangkau oleh siapa saja, termasuk para pekerja yang ingin menambah pengetahuannya, baik dalam bidang yang sama dengan pekerjaan atau mendalami ilmu pendidikan yang berbeda. Robert (2012) mengemukakan bahwa sudah banyak ditemukan fenomena peran ganda mahasiswa, yaitu bekerja sambil kuliah. Artinya tidak menutup kemungkinan untuk seseorang yang sudah bekerja melanjutkan pendidikan di perguruan tinggi.

Universitas Selamat Sri Kendal hadir sebagai jawaban kegelisahan masyarakat atas mahalnya pendidikan tinggi. Dengan biaya pendidikan yang murah, Universitas Selamat Sri memberikan kesempatan pendidikan kepada seluruh lapisan masyarakat untuk mengenyam perkuliahan dan meningkatkan kualitas sumber daya manusianya (uniss.ac.id, 2016). Berdasarkan hasil observasi yang dilakukan pada tanggal 20 Januari 2019, dengan dibukanya perkuliahan bagi mahasiswa yang bekerja di Universitas Selamat Sri banyak masyarakat Kendal yang sudah bekerja mengambil kesempatan tersebut. Berbagai motivasi dan harapan positif akhirnya menghantarkan para pekerja mendaftarkan diri sebagai mahasiswa dan menjadi bagian dari Universitas Selamat Sri. Banyak usaha yang dilakukan oleh mahasiswa yang bekerja diantaranya menyisihkan pendapatan guna membayar biaya pendidikan, meluangkan waktu setelah bekerja dan mengerjakan tugas bahkan penyesuaian diri terhadap perubahan.

Loh, Schutte \& Thorsteinsson (2014) berpendapat bahwa mahasiswa tahun pertama mengalami berbagai perubahan lingkungan, tekanan akademis yang baru dan meningkat, berkurangnya akses ke lingkungan sosial sebelumnya, kebutuhan untuk menciptakan teman sebaya yang baru, dan tanggung jawab pribadi yang meningkat. Jika dikaitkan dengan mahasiswa yang bekerja, hal ini menggambarkan bahwa mahasiswa yang bekerja butuh adaptasi terhadap perubahan yang ada. Tahun pertama dalam kuliah merupakan tahun-tahun adaptasi bagi mahasiswa yang bekerja, hal ini dikarenakan adanya tanggung jawab baru yang harus mereka lakukan atas keputusan mereka sendiri, yaitu bekerja dan kuliah. Prioritas yang semula hanya bekerja, kini jadwal dan tugas kuliah mulai di pertimbangkan, harapannya keduanya mampu berjalan dengan lancar tanpa ada kendala.

Seiring berjalannya dua kegiatan tersebut, tidak bisa di pungkiri bahwa hambatan pun menghampiri. Sebagai contoh bagi mahasiswa yang bekerja di sebuah pabrik dengan peraturan mewajibkan pekerjanya untuk overtime sesuai planning perusahaan dan situasi produksi, dengan demikian mereka harus overtime dan disaat bersamaan mereka juga ada jam kuliah. Secara prioritas mereka memilih untuk overtime dan melewatkan kesempatan belajarnya. Ketika frekuensi overtime tinggi secara otomatis hal ini menjadi satu hambatan bagi mahasiswa yang bekerja (Observasi dan wawancara, tanggal 20 Januari 2019). Hal ini sesuai penelitian Ario (2019) bahwa hambatan mahasiswa dalam menjalani kuliah sambil bekerja adalah terkait manajemen waktu. Berdasarkan hasil penelitian bahwa mengatur waktu antara bekerja dan kuliah tidak mudah untuk dilakukan, terlebih lagi jika waktu kerja tidak fleksibel.

Hambatan-hambatan yang muncul dalam menjalani dua kegiatan tersebut tidak hanya berasal dari pekerjaan saja tetapi bisa berasal dari faktor lain. Sebagai mahasiswa yang bekerja di tahun pertama hal ini terasa sangat sulit, terlebih jika harus melibatkan keputusan besar, semisal dikarenakan ingin lebih serius dalam kuliah maka mahasiswa tersebut memutuskan untuk mengundurkan diri dari pekerjaan. Berdasarkan kenyataan yang ada bahwa dengan bekerjalah mereka dapat membiayai pendidikannya tersebut. Hal ini sependapat dengan Jacinta (2002) bahwa ada beberapa hal yang mendasari seorang mahasiswa untuk bekerja diantaranya adalah kebutuhan finansial, kebutuhan sosial relasional dan kebutuhan aktualisasi diri.

Faktor lain jika mahasiswa lebih mengutamakan pekerjaan, hal yang sering terjadi dalam kuliah adalah kurang maksimal dalam perkuliahan atau memutuskan untuk tidak melanjutkan kuliah. Amirudin (2019) memaparkan data Kemenresdikti, jumlah prosentase mahasiswa putus kuliah tahun 2018 yaitu teknik $4,66 \%$, ekonomi $3,73 \%$, seni $3,59 \%$, humaniora $3,52 \%$, sosial $2,86 \%$, pertanian $2,47 \%$, kesehatan $2,74 \%$, agama $1,62 \%$ dan MIPA $1,30 \%$. Dari data tersebut fakultas teknik mendapat prosentase terbesar, dengan penjelasan bahwa mahasiswa teknik biasanya putus kuliah dikarenakan lebih memilih bekerja.

Fenomena mahasiswa yang bekerja dan tidak melanjutkan kuliah sampai akhir sangat banyak, tetapi banyak pula mahasiswa yang bekerja mampu bertahan

Dipublikasikan Oleh :

UPT Publikasi dan Pengelolaan Jurnal

Universitas Islam Kalimantan Muhammad Arsyad Al-Banjari Banjarmasin 


\section{Mujidah $^{1}$, Laelatul Anisah ${ }^{2}$, Mochamad Widjanarko ${ }^{3}$ \\ Jurnal Mahasiswa BK An-Nur : Berbeda, Bermakna, Mulia \\ Volume 7 Nomor 2 Tahun 2021 \\ Tersedia Online: https://ojs.uniska-bjm.ac.id/index.php/AN-NUR}

p-ISSN. 2460-9722 | e-ISSN. 2622-8297

dan melewati kesulitan-kesulitan yang telah menghampirinya dalam menjalankan kegiatan bekerja dan kuliah. Hal tersebut dikarenakan adanya usaha dan kemampuan untuk menyeimbangkan antara pekerjaan dan perkuliahan. Resiliensi merupakan sebutan untuk seseorang yang mampu bangkit dan melewati kesulitan-kesulitan yang mendekatinya. Cannor and Davidson (2003) mengartikan resiliensi sebagai kemampuan individu yang menjadikan individu tersebut dapat berkembang ditengah kesulitan yang di hadapinya.

Mahasiswa yang bekerja merupakan salah satu posisi yang dekat dengan istilah resiliensi dan menjadi seorang resilien. Hal ini sejalan dengan penelitian Dirmantoro (2015) bahwa mahasiswa yang bekerja memiliki tanggung jawab yang lebih besar dibandingkan mahasiswa pada umumnya. Di satu sisi mahasiswa yang bekerja harus profesional dan produktif dalam pekerjaan, kemudian di sisi yang lain harus menyelesaikan tugas-tugas kuliah yang sudah menjadi pilihannya. Hendriani (2019) menjelaskan resiliensi dalam berbagai kajian dipandang sebagai kekuatan dasar yang menjadi pondasi karakter positif dalam diri seseorang.

Luthar (2003) menyatakan Resiliensi secara umum ditandai oleh sejumlah karakteristik, antara lain: kemampuan dalam menghadapi kesulitan, ketangguhan dalam menghadapi stress ataupun bangkit dari trauma yang dialami. Sedangkan menurut Wang (2016) mahasiswa yang memiliki tingkat resiliensi yang tinggi ditunjukkan dengan karakteristik sebagai berikut: memiliki kemampuan komunikasi, kemampuan organisasi, berkompeten dalam suatu bidang, mampu mengatasi stress, sabar, toleransi, gigih, fleksibilitas, lebih dewasa dan memiliki harga diri. Karakteristik-karakteristik tersebut dapat terlihat dalam kehidupan sehari-hari mahasiswa yang bekerja dan sangat berguna dalam menghadapi suatu permasalahan baik di perkuliahan maupun di pekerjaan.

Grotberg (1999) mendefinisikan resiliensi sebagai kemampuan manusia untuk menghadapi, mengatasi, menjadi kuat ketika menghadapi rintangan dan hambatan. Resiliensi bukan merupakan suatu keajaiban, tidak hanya ditemukan pada sebagian kecil manusia saja dan bukan berasal dari sumber yang tidak jelas. Tetapi setiap manusia sebenarnya memiliki kemampuan untuk belajar bagaimana menghadapi rintangan dan hambatan dalam hidupnya sehingga nantinya menjadi resilien. Adapun aspekaspek resiliensi menurut Grotberg (1999) yaitu I have, I am dan I can.
Resiliensi mahasiswa yang bekerja akan semakin tinggi jika didukung atau berhubungan dengan faktorfaktor lain. Menurut Astuti dan Edwina (2016) konsep diri memiliki hubungan positif atau dapat berkontribusi terhadap resiliensi mahasiswa yang bekerja. Hal ini di karenakan semakin positif konsep diri yang dimiliki akan semakin kuat pula usaha yang dilakukan seseorang dalam menghadapi hambatan yang ada. Sehingga seseorang yang sangat mengenali dirinya akan memiliki kepercayaan diri dan optimis terhadap kemampuan diri sendiri.

Cooper, Krieg dan Brownell (2018) dalam penelitiannya menjelaskan bahwa konsep diri akademis dapat mempengaruhi konstruksi lainnya, dimana konsep diri mahasiswa diartikan sebagai keyakinan mahasiswa pada kemampuan mereka untuk melakukan dan menyelesaikan tugas. Mahasiswa mengembangkan keahliannya dengan mempertimbangkan kemampuan mereka dibandingkan tujuan yang hendak mereka capai. Artinya untuk mencapai suatu tujuan dalam hidup, mahasiswa sangat mempertimbangkan kemampuankemampuan yang dimiliki dan hal ini nantinya sangat berguna dalam proses mencapai tujuan.

Novilita dan Suharnan (2013) mendefinisikan konsep diri sebagai pandangan terhadap diri sendiri, kemudian mengenali dan memahami diri sendiri melalui cara pandang individu dalam melihat diri sendiri sebagai pribadi, dan juga sebagai cara individu merasakan keadaan diri yang sesungguhnya, memiliki harapan ideal terhadap diri serta pandangan yang dimilki orang lain terhadap dirinya. Burns (1993) mengemukakan bahwa seseorang dapat meningkatkan kepercayaan terhadap dirinya dengan memiliki konsep diri yang positif sehingga dapat memotivasi seseorang untuk menjadi lebih baik lagi. Konsep diri ini akan terus berkembang karena diperoleh dari interaksi sosial dan menjadi pandangan, perasaan dan penilaian seseorang terhadap dirinya.

Kiling dan Kiling (2015) berpendapat bahwa konsep diri seseorang tergambar dalam hal-ha yang berkaitan dengan individu tersebut, meliputi pandangan terhadap diri sendiri, hasil evaluasi diri serta harapan terhadap diri sendiri akan membentuk konsep diri individu. Susana (2007) berpendapat bahwa konsep diri yang sehat tidak sekedar positif, tetapi merupakan gambaran tentang diri yang sesuai dengan kenyataan dirinya (real self). Apabila gambaran tentang dirinya, terutama diri yang di citacitakan (ideal self) tidak sesuai dengan kenyataan dirinya, maka akan terjadi ketidaksesuaian antara diri yang dicita-citakan dengan diri yang sesungguhnya

Dipublikasikan Oleh :

UPT Publikasi dan Pengelolaan Jurnal

Universitas Islam Kalimantan Muhammad Arsyad Al-Banjari Banjarmasin 
Berdasarkan beberapa pengertian mengenai konsep diri diatas dapat di terapkan pada mahasiswa yang bekerja, bahwa mahasiswa yang bekerja kemungkinan besar terdapat konsep diri positif dalam dirinya. Hal ini dikarenakan adanya pengenalan dan pemahaman akan gambaran dirinya baik secara fisik, moral, psikis dan sosial yang sesuai kenyataan dirinya (real self). Sehingga mereka menyadari bahwa adanya potensi diri yang perlu di kembangkan, adanya kelemahan yang harus di carikan solusinya, dan tentunya adanya harapan agar mampu menjadi manusia yang lebih baik dari segi kepribadian maupun masa depannya.

Berzonsky (2001) menyatakan bahwa dalam konsep diri terdapat aspek-aspek diantaranya: 1) Aspek Fisik (Physical Self). Meliputi penilaian individu terhadap segala sesuatu yang dimilikinya, seperti tubuh, pakaian dan benda yang dimiliki. 2) Aspek Psikis (Psychological Self). Aspek psikis mencakup pikiran, perasaan dan sikap yang dimiliki terhadap dirinya sendiri. 3) Aspek Sosial (Social Self). Meliputi bagaimana peranan individu dalam lingkungan sosialnya dan penilaian individu terhadap peran tersebut. 4) Aspek Moral (Moral Self). Aspek moral ini merupakan nilai dan prinsip yang dimiliki individu dalam memandang kehidupannya dan nilai etika moral dirinya, seperti kejujuran, tanggung jawab atas kegagalan yang dialaminya, religiusitas serta kesesuaian perilakunya dengan norma-norma masyarakat yang ada.

Penelitian Astuti dan Edwina (2016) mengenai hubungan antara konsep diri dengan resiliensi mahasiswa tahun pertama program kelas karyawan (mahasiswa yang bekerja) menunjukkan hasil adanya hubungan positif yang antara konsep diri dengan resiliensi. Semakin tinggi konsep diri pada mahasiswa tahun pertama program kelas karyawan, maka semakin tinggi pula resiliensi mahasiswa dan sebaliknya. Koefisien determinasi diperoleh sebesar 0,373 , yang berarti $37,3 \%$ resiliensi pada mahasiswa tahun pertama program kelas karyawan dipengaruhi oleh konsep diri.

Konsep diri telah di nyatakan memiliki hubungan positif dengan resiliensi mahasiswa yang bekerja. Selain konsep diri variabel aktualisasi diri juga berperan dalam resiliensi mahasiswa yang bekerja. Menurut Muharami dan Juriana (2013) aktualisasi diri adalah kebutuhan naluriah pada manusia untuk melakukan yang terbaik dari yang manusia bisa. Aktualisasi diri didefinisikan sebagai perkembangan yang paling tinggi dan penggunaan semua bakat pemenuhan semua kualitas dan kapasitas kita. Chaplin (2008) menjelaskan aktualisasi diri adalah kecenderungan untuk mengembangkan bakat dan kapasitas sendiri. Dalam hal ini seseorang berusaha untuk mengembangkan bakat yang dimiliki dan kapasitas dirinya sendiri. Pengembangan bakat dan kapasitas diri di wujudkan dengan sebuah langkah maju kedepan dan tindakan nyata demi tercapainya kapasitas diri yang lebih bernilai. Menurut penelitian Kurniawan, Lestari dan Marta (2016) seseorang dapat dikatakan memiliki aktualisasi diri yang tinggi jika dia termotivasi menjadi individu yang lebih baik dan memiliki keinginan dalam diri untuk lebih maju dari kondisi saat ini.

Menurut Maslow (2018) aktualisasi diri adalah keinginan untuk memperoleh kepuasan dengan dirinya sendiri (self fulfilment), untuk menyadari semua potensi dirinya, untuk menjadi apa saja yang dia dapat melakukannya, dan untuk menjadi kreatif dan bebas mencapai puncak prestasi potensinya. Maslow (2018) menyebutkan aspek-aspek aktualisasi diri diantaranya yaitu persepsi atas realitas, penerimaan, spontanitas, pemusatan pemikiran, kesunyian, otonomi, apresiasi baru, pengalaman puncak, rasa bermasyarakat, kerendahan hati dan kehormatan, relasi interpersonal, etika, cara dan tujuan, humor, kreativitas, resistensi pada enkulturasi, ketidaksempurnaan, nilai-nilai dan resolusi atas dikotomi-dikotomi.

Penelitian Rahmatiah, Hajingo dan Ibrahim (2019) mengenai resiliensi siswa-siswi yang tidak mampu dalam mempertahankan prestasi di sekolah. Dalam penelitian ini yang dimaksud adalah resiliensi siswa dengan latar belakang ekonomi keluarga yang menengah ke bawah dalam mempertahankan prestasi di sekolah. Untuk mengantisipasi ketiadaan dan kekurangan fasilitas belajar dari siswa-siswi tidak mampu, maka diperlukan optimalisasi resiliensi dari siswa-siswi untuk bisa mendapatkan dan mempertahankan prestasinya di sekolah dengan menumbuhkan potensi dirinya (aktualisasi diri) melalui upaya belajar giat dan lainnya.

Uraian diatas menyimpulkan adanya hubungan antara konsep diri dan aktualisasi diri dengan resiliensi mahasiswa yang bekerja. Hal ini dapat digambarkan ketika menjalani kegiatan sebagai mahasiswa yang bekerja tentu akan menemui berbagai hambatan dan rintangan. Suatu rintangan akan menjadikan seseorang lebih kuat dari sebelumnya jika mampu menyelesaikan dan melewatinya dan sebaliknya rintangan dapat menjadikan seseorang menghentikan langkah dalam menuju tujuan yang ingin dicapai (terpuruk).

Dipublikasikan Oleh : 
Mujidah $^{1}$, Laelatul Anisah ${ }^{2}$, Mochamad Widjanarko ${ }^{3}$

Jurnal Mahasiswa BK An-Nur : Berbeda, Bermakna, Mulia

Volume 7 Nomor 2 Tahun 2021

Tersedia Online: https://ojs.uniska-bjm.ac.id/index.php/AN-NUR

p-ISSN. 2460-9722 | e-ISSN. 2622-8297

Setiap mahasiswa yang bekerja pasti memiliki keinginan untuk tetap maju dan mampu melewati rintangan yang ada. Motivasi terkuat untuk bisa melewati rintangan-rintangan tersebut berasal dari diri sendiri, sebagai contoh dengan mengenali diri sendiri (konsep diri) lebih mendalam. Semakin mengenali diri sendiri seorang mahasiswa yang bekerja akan lebih paham bagaimana dirinya yang sebenarnya, apa yang harus dilakukan ketika di hadapkan dengan berbagai rintangan tanpa mengandalkan orang lain.

Faktor dalam diri yang selanjutnya yaitu aktualisasi diri, dapat dipastikan setiap mahasiswa yang bekerja tentu memiliki tujuan-tujuan yang ingin dicapai dan potensi-potensi diri yang ingin dikembangkan. Semakin kuat keinginan untuk mencapai tujuan dan mengembangkan potensi diri tentu semakin kuat pula usaha yang dilakukan untuk melewati segala hambatan dan rintangan yang ada. Sehingga ketika seorang mahasiswa yang bekerja memiliki konsep diri dan aktualisasi diri yang tinggi maka akan memiliki kemampuan untuk menghadapi dan bangkit dari hambatan yang ada yang disebut dengan istilah resiliensi.

\section{METODE}

Penelitian ini termasuk penelitian kuantitatif yang meneliti hubungan antara variabel terikat dan variabel bebas. Populasi dalam penelitian ini adalah seluruh mahasiswa Universitas Selamat Sri Kendal yang bekerja. Penelitian ini menggunakan subjek peneitian sebanyak 50 mahasiswa yang bekerja dengan teknik aksidental sampling.

Variabel terikat dalam penelitian ini adalah resiliensi mahasiswa yang bekerja. Dalam penelitian ini resiliensi diukur berdasarkan skala resiliensi yang disusun berdasarkan aspek-aspek resiliensi menurut Grotberg (1999) yang meliputi I have, I am, dan I can.

Adapun variabel bebas dalam penelitian ini adalah konsep diri dan aktualisasi diri mahasiswa yang bekerja. Dalam penelitian ini konsep diri diukur berdasarkan skala konsep diri yang disusun berdasarkan aspek-aspek konsep diri menurut Berzonsky (2001) yang meliputi aspek fisik, aspek psikis, aspek moral dan aspek sosial. Sedangkan dalam aktualisasi diri diukur berdasarkan skala aktualisasi diri yang disusun berdasarkan aspek-aspek aktualisasi diri menurut Maslow (2018) yang meliputi persepsi atas realitas, penerimaan, spontanitas, pemusatan pemikiran, kesunyian, otonomi, apresiasi baru, pengalaman puncak, rasa bermasyarakat, kerendahan hati dan kehormatan, relasi interpersonal, etika, cara dan tujuan, humor, kreativitas, resistensi pada enkulturasi, ketidaksempurnaan, nilai-nilai dan resolusi atas dikotomi-dikotomi.

Data penelitian dikumpulkan menggunakan metode kuesioner (skala). Menurut Sugiyono (2019) kuesioner atau angket adalah teknik pengumpulan data yang dilakukan dengan cara memberi seperangkat pertanyaan atau pertanyaan tertulis kepada responden untuk dijawabnya. Skala yang digunakan dalam penelitian ini adalah skala Likert. Skala likert ini didesain untuk menelaah seberapa kuat subyek setuju atau tidak setuju dengan pernyataan pada skala empat titik ini.

Analisis data yang digunakan dalam penelitian ini adalah analisis multple linear regression. Penggunaan analisis multiple linier regression dengan mempertimbangkan penelitian ini memilki dua variabel bebas yaitu konsep diri dan aktualisasi diri serta satu variabel tergantung yaitu resiliensi mahasiswa yang bekerja. Sedangkan untuk analisis hipotesis minor digunakan product moment dengan bantuan Statistical Product and Service Solution (SPSS) 16.0 for windows.

\section{HASIL DAN PEMBAHASAN}

\section{Uji Normalitas Hubungan}

Uji normalitas dilakukan untuk melihat apakah data dan sebaran data mengikuti kurva normal atau tidak. Uji normalitas dilakuakan dengan teknik Kolmogorov - Smirnov. Hasil uji normalitas pada variabel konsep diri nilai $\mathrm{K}-\mathrm{S}=$ 0,619 dengan $\mathrm{p}=0,838 \quad(\mathrm{p}>0,05)$, dan uji normalitas pada variabel aktualisasi diri diperoleh nilai $\mathrm{K}-\mathrm{S}=1,003$ dengan $\mathrm{p}=0,266(\mathrm{p}>0,05)$, sedangkan uji normalitas pada variabel resiliensi diperoleh nilai $\mathrm{K}-\mathrm{S}=0,683$ dengan $\mathrm{p}=0,739$ $(\mathrm{p}>0,05)$. Berdasarkan hasil uji normalitas ini menunjukkan bahwa ketiga variabel tersebut memiliki sebaran data yang normal.

\section{Uji Linieritas Hubungan}

Berdasarkan hasil uji linieritas menunjukkan korelasi antara konsep diri dengan resiliensi mahasiswa yang bekerja yang diperoleh dari $\mathrm{F}$ linier $=53.373$ dengan $\mathrm{p}=0,000(\mathrm{p}<0,05)$. Sedangkan korelasi antara aktualisasi diri dengan resiliensi mahasiswa yang bekerja yang diperoleh dari $\mathrm{F}$ linier $=23,905$ dengan $\mathrm{p}=0,000(\mathrm{p}<0,05)$. Angka tersebut menunjukkan bahwa adanya hubungan yang bersifat linier.

\section{Uji Multikolinieritas}

Uji multikolinieritas adalah uji yang dilakukan untuk memastikan apakah di dalam

Dipublikasikan Oleh : 
Mujidah $^{1}$, Laelatul Anisah ${ }^{2}$, Mochamad Widjanarko ${ }^{3}$

Jurnal Mahasiswa BK An-Nur : Berbeda, Bermakna, Mulia

Volume 7 Nomor 2 Tahun 2021

Tersedia Online: https://ojs.uniska-bjm.ac.id/index.php/AN-NUR

p-ISSN. 2460-9722 | e-ISSN. 2622-8297

sebuah model regresi ada interkorelasi atau kolinieritas antar variabel bebas. Hasil uji multikolinieritas menunjukkan bahwa antar variabel independen (konsep diri dan aktualisasi diri) tidak terjadi multikolinieritas, karena nilai tolerance variabel konsep diri 0,809 berarti berada diatas 0,1 , dan nilai tolerance variabel aktualisasi diri 0,809 berarti juga diatas 0,1 . Sedangkan jika dilihat berdasarkan nilai VIF baik variabel konsep diri maupun variabel aktualisasi diri memiliki nilai 1,236 berarti nilai VIF variabel konsep diri dan aktualisasi diri berada di bawah 10 .

\section{Uji Hipotesis}

a. Hipotesis Mayor

Pengujian hipotesis penelitian dilakukan dengan bantuan perhitungan program SPSS 16.0 for windows dengan teknik korelasi Analisis Regresi dua predictor, berdasarkan hasil perhitungan hasilnya enunjukkan koefisien korelasi dari ketiga variabel $\mathrm{R} x 1, \mathrm{x} 2$, $\mathrm{y}=0,751$ dengan $\mathrm{F}=30,480$ dan $\mathrm{p}=0,000(\mathrm{p}<$ 0,01 ) ini berarti ada hubungan yang sangat signifikan antara konsep diri, aktualisasi diri dengan resiliensi mahasiswa yang bekerja di Universitas Selamat Sri Kendal. Dengan demikian hipotesis mayor yang diajukan dalam penelitian ini diterima.

b. Hipotesis Minor Konsep Diri dengan Resiliensi

Berdasarkan hasil analisis diketahui bahwa besarnya koefisien antara kedua variabel $\mathrm{r} x 1, \mathrm{y}=0,717$ dengan $\mathrm{p}=0,000$ $(p<0,01)$. Hal ini menunjukkan bahwa ada hubungan positif yang sangat signifikan antara variabel konsep diri dengan resiliensi. Artinya semakin tinggi konsep diri maka semakin tinggi tingkat resiliensi mahasiswa yang bekerja tersebut dan sebaliknya. Dengan demikian hipotesis minor satu yag diajukan dalam penelitian ini diterima.

c. Hipotesis Minor Aktulisasi Diri dengan Resiliensi

Berdasarkan hasil analisis diketahui bahwa besarnya koefisien antara kedua variabel $\mathrm{r} x 2, \mathrm{y}=0,515$ dengan $\mathrm{p}=0,000$ $(\mathrm{p}<0,01)$. Hal ini menunjukkan bahwa ada hubungan positif yang sangat signifikan antara variabel aktualisasi diri dengan resiliensi. Artinya semakin tinggi aktualisasi diri maka semakin tinggi tingkat resiliensi mahasiswa yang bekerja tersebut dan sebaliknya. Dengan demikian hipotesis minor dua yang diajukan dalam penelitian ini diterima.

\section{Pembahasan}

Berdasarkan analisis data diketahui $\mathrm{R} \times 1, \mathrm{x} 2$, $\mathrm{y}=0,751$ dengan $\mathrm{F}=30,480$ dan $\mathrm{p}=0,000$ $(\mathrm{p}<0,01)$ dengan persamaan regresi yaitu $\mathrm{Y}=$ $14,669+0,617 \mathrm{X} 1+0,327 \mathrm{X} 2$, ini berarti ada hubungan yang sangat signifikan antara konsep diri, aktualisasi diri dengan resiliensi mahasiswa yang bekerja di Universitas Selamat Sri Kendal. Dengan demikian hipotesis mayor yang diajukan dalam penelitian ini diterima.

Berdasarkan penjelasan dari persamaan regresi diatas menunjukkan jika konsep diri dan aktualisasi diri nilainya 0,617 dan 0,327, maka resiliensi nilainya adalah 14,669 . Koefisien regresi variabel konsep diri sebesar 0,617 artinya jika variabel indpenden lain nilainya tetap dan variabel konsep diri mengalami kenaikan 1\% maka resiliensi akan mengalami kenaikan sebesar 14,669. Koefisien regresi konsep diri bernilai positif artinya terjadi hubungan positif antara konsep diri dengan resiliensi mahasiswa yang bekerja, semakin naik naik konsep diri maka semakin naik tingkat resiliensi mahasiswa yang bekerja. Sedangkan pada koefisien regresi aktualisasi diri memiliki nilai 0, 327 artinya jika variabel independent lain nilainya tetap dan aktualisasi diri mengalami kenaikan 1\%, maka resiliensi akan mengalami peningkatan sebesar 14,669. Koefisien regresi aktualisasi diri bernilai positif artinya terjadi hubungan positif aktualisasi diri dengan resiliensi mahasiswa yang bekerja, semakin naik aktualisasi diri maka akan semakin naik tingkat resiliensi mahasiswa yang bekerja.

Hasil uji hipotesis pertama dari hasil pengolahan data menunjukkan adanya koefisien korelasi rx1y $=0,717$ dengan $\mathrm{p}=0,000(\mathrm{p}<0,01)$. Hal ini menunjukkan bahwa ada hubungan positif yang sangat signifikan antara variabel konsep diri dengan resiliensi. Artinya semakin tinggi konsep diri maka semakin tinggi pula tingkat resiliensi pada mahasiswa yang bekerja sebaliknya semakin rendah konsep diri maka semakin rendah pula resiliensi mahasiswa yang bekerja. Dengan demikian hipotesis minor satu yang diajukan dalam penelitian ini di terima.

Berdasarkan pernyataan tersebut maka peneliti setuju dengan pernyataan Amalia (dalam Astuti dan Edwina, 2017) yang menyatakan bahwa konsep diri dengan segala aspek yang terkandung didalamnya (fisik, psikis, sosial dan

Dipublikasikan Oleh :

UPT Publikasi dan Pengelolaan Jurnal

Universitas Islam Kalimantan Muhammad Arsyad Al-Banjari Banjarmasin 
Mujidah $^{1}$, Laelatul Anisah ${ }^{2}$, Mochamad Widjanarko ${ }^{3}$

Jurnal Mahasiswa BK An-Nur : Berbeda, Bermakna, Mulia

Volume 7 Nomor 2 Tahun 2021

Tersedia Online: https://ojs.uniska-bjm.ac.id/index.php/AN-NUR p-ISSN. 2460-9722 | e-ISSN. 2622-8297

moral) memang memberikan kontribusi terhadap resiliensi individu. Konsep diri memiliki kontribusi yang positif terhadap resiliensi sehingga semakin positif konsep diri makan semakin tinggi resiliensi tersebut. Sehingga memiliki konsep diri menjadi salah satu cara untuk dapat meningkatkan daya resiliensi individu.

Hasil uji hipotesis kedua menunjukkan adanya koefisien korelasi $\mathrm{r} x 2 \mathrm{y}=0,515$ dengan $\mathrm{p}$ $=0,000(\mathrm{p}<0,01)$. Hal ini menunjukkan bahwa ada hubungan positif yang sangat signifikan antara variabel aktualisasi diri dengan resiliensi. Artinya semakin tinggi aktualisasi diri maka semakin tinggi tingkat resiliensi mahasiswa yang bekerja tersebut dan sebaliknya apabila semakin rendah aktualisasi diri maka semakin rendah pula tingkat resiliensi mahasiswa yang bekerja. Dengan demikian hipotesis minor dua yang diajukan dalam penelitian ini diterima.

Siswandi (dalam Syauta dan Yuniasanti, 2015) menyatakan bahwa dalam memenuhi kebutuhan aktualisasi diri, individu berjuang mencapai kesehatan dan kesejahteraan emosional, cukup memiliki kepercayaan diri serta tersedianya kesempurnaan yang lebih memungkinkan individu mengembangkan motif-motif dalam diri secara terus menerus, untuk memperhatikan, memelihara, dan mendukung pertumbuhan diri. Lebih lanjut yang terpenting adalah individu harus mempunyai identitas yang mantap dan tidak mudah terombang-ambing oleh kekuatan sosial lain yang mencampuri kecenderungan kodrat untuk tumbuh. .

Hasil yang diperoleh dari uji hipotesis menunjukkan $\mathrm{R}$ (square) adalah 0,565. Hal ini berarti sumbangan efektif konsep diri dan aktualisasi diri terhadap resiliensi mahasiswa yang bekerja di Universitas Selamat Sri Kendal sebesar $56,5 \%$ dan sisanya sebesar $43,5 \%$ dipengaruhi oleh faktor lain. adapun tabel sumbangan efektif tiap variabel dapat dilihat pada Tabel 4.13.

Tabel 1

Sumbangan Efektif

\begin{tabular}{cc}
\hline Keterangan & Sumbangan Efektif \\
\hline Konsep Diri (X1) & $43,6 \%$ \\
Aktualisasi Diri (X2) & $12,9 \%$ \\
\hline Total & $56,5 \%$ \\
\hline
\end{tabular}

Tabel 1 diatas, memaparkan besarnya sumbangan efektif yang diberikan oleh masing-masing variabel bebas terhadap variabel tergantung, dimana konsep diri memberikan pengaruh terhadap resiliensi mahasiswa yang bekerja di Universitas Selamat Sri Kendal sebesar 43,6\% $(\beta=0,717)$ dan aktualisasi diri memberikan pengaruh terhadap resiliensi mahasiswa Universitas Selamat Sri Kendal yang bekerja sebesar 12,9\% $(\beta=0$, 515).

Tabel 2

Kategorisasi

\begin{tabular}{lcccccc}
\hline Keterangan & \multicolumn{2}{c}{ Resiliensi } & \multicolumn{2}{c}{ Konsep Diri } & \multicolumn{2}{c}{ Aktualisasi Diri } \\
\cline { 2 - 7 } & $\mathrm{F}$ & $\%$ & $\mathrm{~F}$ & $\%$ & $\mathrm{~F}$ & $\%$ \\
\hline Rendah & 5 & $10 \%$ & 6 & $12 \%$ & 2 & $4 \%$ \\
Sedang & 37 & $74 \%$ & 32 & $64 \%$ & 35 & $70 \%$ \\
Tinggi & 8 & $16 \%$ & 12 & $24 \%$ & 13 & $26 \%$ \\
\hline Total & 50 & $100 \%$ & 50 & $100 \%$ & 50 & $100 \%$ \\
\hline
\end{tabular}

Dipublikasikan Oleh :

UPT Publikasi dan Pengelolaan Jurnal

Universitas Islam Kalimantan Muhammad Arsyad Al-Banjari Banjarmasin 
Mujidah $^{1}$, Laelatul Anisah ${ }^{2}$, Mochamad Widjanarko ${ }^{3}$

Jurnal Mahasiswa BK An-Nur : Berbeda, Bermakna, Mulia

Volume 7 Nomor 2 Tahun 2021

Tersedia Online: https://ojs.uniska-bjm.ac.id/index.php/AN-NUR

p-ISSN. 2460-9722 | e-ISSN. 2622-8297

Tabel 2 diatas, menunjukkan bahwa mahasiswa Universitas Selamat Sri Kendal yang bekerja memiliki tingkat resiliensi, konsep diri dan aktualisasi diri dalam kategori sedang.

Penelitian ini masih terdapat beberapa kelemahan. Adapun beberapa kemungkinan yang menyebabkan penelitian ini memiliki beberapa kelemahan diantaranya:

1) Melalui penyebaran kuesioner dengan google formulir ini membuat responden tidak dapat dipastikan untuk langsung mengisi kuesioner penelitian, jadi peneliti harus menunggu beberapa hari.

2) Banyak responden yang tidak bisa membantu mengisi kuesioner dikarenakan kesibukan dalam bekerja.

3) Banyaknya item pernyataan yang harus diisi oleh responden.

4) Pengambilan subjek penelitian menjadi lebih random, artinya untuk memenuhi jumlah target subjek penelitian, yang awalnya hanya diperuntukkan bagi mahasiswa tingkat akhir menjadi mengikutsertakan mahasiswa semester 2, 4 dan 6 dengan kriteria mahasiswa yang bekerja.

Jumlah responden yang didapatkan sedikit, sehingga menggunakan teknik sampling/ try out terpakai.

\section{PENUTUP}

1. Adanya hubungan antara konsep diri dan aktualisasi diri dengan resiliensi mahasiswa Universitas Selamat Sri Kendal yang bekerja. Berdasarkan analisis data diketahui $\mathrm{R} x 1, \mathrm{x} 2, \mathrm{y}=$ 0,751 dengan $\mathrm{F}=30,480$ dan $\mathrm{p}=0,000(\mathrm{p}<0,01)$ dengan persamaan regresi yaitu $\mathrm{Y}=14,669+$ $0,617 \mathrm{X} 1+0,327 \mathrm{X} 2$, ini berarti ada hubungan yang sangat signifikan antara konsep diri dan aktualisasi diri dengan resiliensi mahasiswa Universitas Selamat Sri Kendal yang bekerja. Dengan demikian hipotesis mayor yang diajukan dalam penelitian ini diterima.

2. Adanya hubungan antara konsep diri dengan resiliensi mahasiswa Universitas Selamat Sri Kendal yang bekerja. Berdasarkan analisis data di dapatkan persamaan regresi $\mathrm{Y}=14,669+0,617 \mathrm{X} 1$ + 0,327 X2 maka koefisien regresi variabel konsep diri (X1) sebesar 0,617 artinya jika variabel independen lain nilainya tetap dan variabel konsep diri mengalami kenaikan $1 \%$ maka resiliensi akan mengalami kenaikan sebesar 14,669. Sedangkan berdasarkan hasil penelitian bahwa konsep diri memberikan sumbangan efektif sebesar 43,6\% terhadap resiliensi mahasiswa yang bekerja. Sedangkan berdasarkan hasil penelitian bahwa konsep diri memberikan sumbangan efektif sebesar 43,6\% terhadap resiliensi mahasiswa yang bekerja.

3. Adanya hubungan antara aktualisasi diri dengan resiliensi mahasiswa Universitas Selamat Sri Kendal yang bekerja. Berdasarkan analisis data di dapatkan persamaan regresi $\mathrm{Y}=14,669+0,617 \mathrm{X} 1$ $+0,327 \mathrm{X} 2$ maka koefisien regresi variabel aktualisasi diri (X2) sebesar 0,327, artinya jika variabel independen lain nilainya tetap dan variabel aktualisasi diri mengalami kenaikan $1 \%$ maka resiliensi akan mengalami kenaikan sebesar 14,669. Sedangkan berdasarkan hasil penelitian bahwa aktualisasi diri memberikan sumbangan efektif sebesar $12,9 \%$ terhadap resiliensi mahasiswa yang bekerja.

4. Mahasiswa Universitas Selamat Sri Kendal yang bekerja memiliki tingkat resiliensi, konsep diri dan aktualisasi diri dalam kategori sedang, dengan prosentase resiliensi sebesar $74 \%$, konsep diri sebesar $64 \%$ dan aktualisasi diri sebesar $70 \%$.

\section{REFERENSI}

Amiruddin. (2019). Mahasiswa Teknik Paling Banyak Putus Kuliah, Data Kemenristekdikti 2018! Apa Kuliahnya Berat?. Diperoleh dari https://www.google.com/amp/s/makassar.tribunne ws.com/amp/2019/03/30/mahasiswa-teknikpaling-banyak-putus-kuliah-data-

kemenristekdikti-2018-apa-alasan-kuliahnyaberat/ diunduh pada 1 April 2020 jam 22.00 WIB

Ario, T. S. (2019). Problematika Pada Mahasiswa Pekerja Paruh Waktu "Part Time". Skripsi. Universitas Muhammadiyah Surakarta.

Astuti, F dan Edwina, T. N (2017). Resiliensi Pada Mahasiswa Tahun Pertama Program Kelas Karyawan Ditinjau Dari Konsep Diri. Prosiding SEMNAS Penguatan Individu Di Era Revolusi Informasi. 143-152. 
Mujidah $^{1}$, Laelatul Anisah ${ }^{2}$, Mochamad Widjanarko ${ }^{3}$

Jurnal Mahasiswa BK An-Nur : Berbeda, Bermakna, Mulia

Volume 7 Nomor 2 Tahun 2021

Tersedia Online: https://ojs.uniska-bjm.ac.id/index.php/AN-NUR

p-ISSN. 2460-9722 | e-ISSN. 2622-8297

Berzonsky. (2001). Moral Develompment Child. USA: The Mac Millan Psychology References Series.

Chaplin, J. P. (2008). Kamus Psikologi Lengkap. Jakarta: PT. Raja Grafindo

Cholily. A. H. (2014). Hubungan Antara Konsep Diri Dengan Resiliensi Pada Mahasiswa Fakultas Psikologi Angkatan 2010-2013 Universitas Islam Negeri Maulana Malik Ibrahim Malang. Skripsi. Universitas Malik Ibrahim Malang

Cooper, K. M., Krieg, A \& Brownell, S.E. (2018). Who Perceives They Are Smarter? Exploring The Influence Of Student Characteristics On Student Academic Self- Concept In Psysiologi. Advances in Physiologi Education. 42, 200-208

Hendriani, W. (2019). Resiliesnsi Psikologis Sebuah Pengantar. Jakarta: Prenadamedia Group.

Jacinta, R. F. (2002). Wanita bekerja. WEB: Kompas Cyber Media.

Jamaludin, A (2016). Perbandingan Hasil Belajar Antara Mahasiswa Yang Bekerja Dengan Yang Tidak Bekerja Pada Matakuliah Ekonomi Mikro di STIE YPBI Jakarta. Jurnal Administrasi Kantor. 4(1), 198-210.

Kiling, B. N dan Kiling, I. Y (2015). Tinjauan Konsep Diri Dan Dimensinya Pada Anak Dalam Masa Kanak-Kanak Akhir. Jurnal Psikologi Pendidikan Dan Konseling. 1(2), 116-124.

Kurniawan, A., Lestari, S \& Martha, R. (2016). Efektifitas Teknik Paper Seminar Untuk Mengajar Menulis Ditinjau dari Aktualisasi Diri Mahasiswa. Jurnal LPPM. 3(1), 23-30

Loh, J. M. I., Schutte, N. S \& Thorsteinsson, E. B. (2014). Be Happy: The Role of Resilience between Characteristic Affect and Symptoms of Depression. Journal of Happiness Studies.15, 1125-1138.

Luthar, S. S. (2003). Resilience and Vulnerability: Adaptation in the Context of Childhood Adversities. Cambridge University Press.
Maslow, A. H (2018). Motivation and Personality (Motivasi dan Kepribadian). Yogyakarta: Cantrik Pustaka.

Muharami, W.A.H dan Juriana (2013). Aktualisasi Diri Anggota Klub Sofbol Universitas Negeri Jakarta. Jurnal Olahraga Kreasi. 2(01). 107-112.

Mulyati, R (2009). Resiliensi Remaja "High-Risk" Ditinjau Dari Faktor Protektif. Jurnal Psikologika. 14(1), 35-53.

Novilita, H dan Suharnan (2013). Konsep Diri Adversity Quotient dan Kemandirian Belajar Siswa. Jurnal Psikologi. 8(1). 619-632.

Rahmatiah, Hajingo, I \& Ibrahim, R. (2019). Resiliensi Siswa-Siswi Tidak Mampu dalam Mempertahankan Prestasi di Sekolah. Seminar Nasional Teknologi, Sains dan Humaniora. 376381

Robert, P \& Saar, E. (2012). Learning and Working: Impact of the 'Double Status Position' on the Labour Market Entry Process of Graduates in CEE Countries. Europian Sociological Review, 28(6), 742-754

Schultz, D. (1991). Psikologi Pertumbuhan, ModelModel Kepribadian Sehat. Yogyakarta: Kanisius

Styowati, A., Hartati, S \& Sawitri, D. R. (2010). Hubungan Kecerdasan Emosional dengan Resiliensi pada Siswa Penghuni Rumah Damai. Jurnal Psikologi Undip. 7(1), 67-77

Sugiyono (2019). Metode Penelitian Kuantitatif Kualitatif dan $R \& D$. Bandung: Alfabeta.

Susana, T. (2007). Konsep Diri Positif Menentukan Prestasi Anak. Yogyakarta: Kanisius

Syauta, A. B. \& Yuniasanti, R. (2015). Hubungan Antara Kebutuhan Aktualisasi Diri Dengan Motivasi Kerja Pada Wanita Karier Di PT Kusuma Sandang Mekar Jaya. Insight. 17(1), 49-55

UNISS. (2016). Mengenal UNISS Lebih Dekat. Diunduh dari https://uniss.ac.id/mengenal-unisslebih-dekat/ diunduh pada 23 Juli 2020 jam 23.00 WIB.

Dipublikasikan Oleh :

UPT Publikasi dan Pengelolaan Jurnal

Universitas Islam Kalimantan Muhammad Arsyad Al-Banjari Banjarmasin 
Mujidah $^{1}$, Laelatul Anisah ${ }^{2}$, Mochamad Widjanarko ${ }^{3}$ Jurnal Mahasiswa BK An-Nur : Berbeda, Bermakna, Mulia Volume 7 Nomor 2 Tahun 2021

Tersedia Online: https://ojs.uniska-bjm.ac.id/index.php/AN-NUR p-ISSN. 2460-9722 | e-ISSN. 2622-8297

Wang, Jung. (2016). A Study of Resiliency Characteristics in the Adjusment of Internasional Graduate Student at American Universities. Journal of Studies In Internasional Education. 10(10), 1-24

Dipublikasikan Oleh :

UPT Publikasi dan Pengelolaan Jurnal

Universitas Islam Kalimantan Muhammad Arsyad Al-Banjari Banjarmasin 